\title{
Researching Effects of Information Technologies Usage in Engineering Graphics Teaching
}

\author{
Eleonora Desnica \\ Technical faculty "Mihajlo \\ Pupin", Zrenjanin, \\ University of Novi Sad, Serbia
}

desnica@tfzr.uns.ac.rs

Duško Letić

Technical faculty "Mihajlo

Pupin", Zrenjanin, University of Novi Sad, Serbia

dletic@tfzr.uns.ac.rs

\author{
Biljana Gemović \\ The Higher Education \\ Technical School of \\ Professional Studies, Novi Sad, \\ Serbia \\ gemovic@vtsns.edu.rs \\ Radojka Gligorić \\ Faculty of Agriculture, \\ University of Novi Sad, Serbia \\ gligrad@polj.uns.ac.rs
}

\begin{abstract}
Universities and their faculties and colleges have a very complex function in society today, so it is necessary for them to establish the right balance when executing their tasks. On the other hand, economy has a need and obligation to invest in university educated personnel able to apply and develop new technological achievements. The paper presents new trends in technology and higher education of technical engineers which could be of great importance in future development of distance learning (e-learning). It also underlines the attempt of using the innovative models of work, which are presented and experimentally confirmed, to show a gradual transmission from traditional to a new view to engineering graphics teaching. Statistical analysis of the obtained results has confirmed that a distance learning model in engineering graphics teaching has a statistically relevant effect on teaching efficiency.
\end{abstract}

Keywords: engineering graphics, computer aided design (CAD), education of technical engineers, distance learning, statistical test.

\section{Introduction}

Distinctive features of modern society are dynamic changes, intensive development of manufac-

Material published as part of this publication, either on-line or in print, is copyrighted by the Informing Science Institute. Permission to make digital or paper copy of part or all of these works for personal or classroom use is granted without fee provided that the copies are not made or distributed for profit or commercial advantage AND that copies 1) bear this notice in full and 2) give the full citation on the first page. It is permissible to abstract these works so long as credit is given. To copy in all other cases or to republish or to post on a server or to redistribute to lists requires specific permission and payment of a fee. Contact Publisher@InformingScience.org to request redistribution permission. turing, information and telecommunication technologies, which are all prerequisites for qualitative changes in all spheres of society, especially in education. New educational models with new educational technology can improve efficiency of educational process and learning process. Many foreign educational institutions have tried to solve this problem by development of distance 
learning model. A rapidly increasing number of online classes and programs prompt researchers and pedagogues to focus on online interactions (Miltenof, Hoover, \& Tzokov, 2008).

The latest achievements in information and communication teaching technologies must be analyzed and followed permanently. The use of information technologies will enable creation of a new basis and possibilities aimed at advancing of teaching process. The past ten years has seen a rapid increase in Internet use (Saade \& Huang 2008). Society needs to prepare qualified and skilled people to pave the way for a breakthrough of new information technologies in education system.

Modern design and engineering design in mechanical engineering, construction industry, architecture, traffic, electrical engineering and other is a complex task, which is today mainly supported by methods of computer technologies. Computer methods and technologies of the $\mathrm{CAD} / \mathrm{CAE}$ (computer aided design/computer aided engineering) type have contributed to an essentially new approach to the process of designing and engineering designing in recent years. Knowing the theory of design should be an element of the general professional knowledge of each engineer of technical disciplines (Lee, 1999).

Every engineer or technician needs to know how to express their ideas through technical drawing. As a means to express ideas, a drawing allows communication with all mankind (Bertoline \& Wiebe 2002). A concept of research carried out under the title of "Innovative pedagogical approach in engineering graphics teaching in higher technical education" is presented in this paper. The goal of this research was to establish two things. The first one is the efficiency of engineering graphics teaching in higher technical education realized by means of a distance learning model and the second one is the outreach of the effect of a new educational orientation in teaching new contents by means of modern information technologies. The research was carried out in 2008/2009 and 2009/2010 (winter semester) academic year during Technical drawing with computer graphics classes at the Technical Faculty "Mihajlo Pupin" in Zrenjanin at the following departments: Industrial engineering and Engineering Management. The paper (Desnica, Letic, \& Navalusic, 2010) presents a similar research which was carried out only for the 2008/2009 academic year with fewer students.

This article analyzes educational trends and experiences concerning the possibilites of distance learning application in university level education and importance of engineering graphics in the education of technical engineers. Basic components of the model are described along with a projected scenario for the model implementation: from preparation of the teaching material, program environment for learning process management and work strategy, through implementation of the teaching process itself, to assessment of students and the quality control of the operation of the system.

\section{Experiences in Distance Learning}

Increasing and improving of efficiency of educational and learning process can be effected by development of new educational models with application of new technologies. Distance learning means that in educational process users and instructors are physically separated and technologies (radio, video, printed material, computer data) are used to bridge this distance. It is clear that physical separation of students and teachers is overcome by use of information technologies. (Herrero-Martin, Solano-Fernandez, \& Solano-Fernandez, 2008).

These programs often offer a second chance to get a university level education by solving a problem of lack of time, distance or physical inability and they allow users to broaden their knowledge without leaving their place of work. 
Distance learning is at the same time a challenge and tool for improvement and advancement of educational process and one of the foundation stones for new and betted ways of knowledge management. Intensive introduction of information technologies in educational processes has become a priority of modern institutions for higher and further education worldwide (Rogers, 2009).

Thanks to its mobility, flexibility and effectiveness, distance learning is becoming an ideal model which allows for a combination of "old" and "new", "traditional" and "modern". In less than a decade traditional models of education and business have faced new experience, tools and needs. In the conditions of technical-information revolution which absolutely affects the society, the aim of education system is to respond to these new conditions with the least possible increase in financial resources. In such conditions new modes of socialization are created as well as new types of individual and collective identity; autodidactic teaching methods and distance learning methods are developed to improve individualization of learning because new technologies of education allow for exchange of information and knowledge without relatively big investments. Statistics show that millions of students worldwide are involved in some form of distant learning. The task of modern education is to qualify people for life and work in a society of fast technologic changes, to develop their awareness of the need for permanent, life-long learning and for mastering learning techniques. A great number of famous higher education institutions in the world offer distant learning through seriously organized programs and content of study within their curricula (Rosenberg, 2006).

Distance learning development has reached one of the turning points in the world today (Bates, 2001). A great number of world recognized higher education institutions have introduced this category of learning in their programs of study as a compulsory and contemporary manner of education. These are well-thought programs which involve a great number of students. In Europe there are important initiatives for distance learning development implemented through European Distance Education Network (EDEN) and European association of Distance Education Teaching Universities (EADTU). Open University in the UK has set some standards for this type of education which served as a model for institutions organizing distance learning in Spain, Germany, the Netherlands and Portugal. In its documents, such as e-learning Action Plan, the European Commission strongly supports development of distance learning, i.e. e-education in all EU member states. The European Commission has elaborated a precise plan to offer distance learning and eeducation to students in universities in all member states. The resolution of the European Council gives priority to this kind of education in further development of education in the EU.

\section{Educational Trends in Universities in Serbia}

As for the transition in education, we find ourselves now on a path between a well guarded fortress of traditional school and the school which the pupils, teachers, local communities and society in general need, the school which must adjust quickly to dramatic social changes, respond adequately to those changes and which is adaptable. Obviously, the education in our country is still attached to traditional teaching, so the distant learning model is not enough implemented and is only treated as additional service to help the students. Unfortunately, using these solutions in conditions characteristic for our country is limited with series of factors such as high price of packages, necessity of being well educated in information, a good command of English language by teachers and students, a good information-communication technology.

Implementation of distance learning in Serbia is not strategically founded and has no detailed plan of development. Certain institutions have started their own distance learning systems; however, most of those projects have failed due to financial reasons or poor organization of the project itself. Individual cases which can be found in our environment: Technical Faculty in Čačak, master studies for electronic learning-www.e-lab.tfc.kg.ac.rs; Faculty of Mechanical Engineering in Kragujevac - www.mfkg.kg.ac.rs; Faculty of Mechanical Engineering in Belgrade, electronic 
classroom - www.mas.bg.ac.rs; Faculty of organizational sciences - www.fon.rs (Desnica, Letic \& Navalusic, 2010).

\section{Engineering Graphics Teaching at Faculties in the Country and Abroad}

University and its faculties and colleges have a very complex role in society today. Designing a suitable educational process will best satisfy the needs for graduate technical engineers of great competence to acquire and develop new knowledge and become trained to solve technical and managerial problems.

Considering the fact that mechanical engineering belongs to the group of progressive sciences and that it is one of the pillars of technological development, that it permanently changes and improves, it seems necessary for engineers themselves to keep being intensively educated and to improve their knowledge and skills. There is an obvious need to revise education for engineers as a response to changes in society. Engineers dream to have everything they need for their work: a series of practical and theoretical data in electronic from, no need to use books, manuals, tables, etc. By using modern software this objective of engineers and technicians can certainly be attained (Letic \& Desnica, 2007).

Graphic communication is one of forms of communication and all graphic forms are especially important for an engineer and technical science. Engineering graphics is a language used by engineers to transfer ideas and information necessary to design new technical appliances and systems. This language includes drawings, sketches, plans, arrangements, diagrams, remarks and instructions. In engineering, graphics has three main goals: to analyze and show designs, transfer information about designs and note development of designs and all the changes in it (Gligoric \& Milojevic, 2004).

Some of the faculties with the courses in engineering graphic communications are: University of Novi Sad, Faculty of technical science (Engineering graphic communications); University of Novi Sad, Technical faculty «Mihajlo Pupin», Zrenjanin (Technical drawing with computer graphics); Higher education technical school of professional studies, Novi Sad (Computer graphics and CAD); Faculty of Mechanical Engineering, Beograd (Engineering graphics); Faculty of Mechanical Engineering, Niš (Engineering graphics); Faculty of Mechanical Engineering, Kragujevac (Technical drawing with computer graphics); University of Ljubljana, Faculty of Mechanical Engineering (Technical documentation); Faculty of Mechanical Engineering, Banja Luka (Engineering graphics); Faculty of Mechanical Engineering, Podgorica (Engineering graphics); University of Glasgow, Faculty of Engineering (Product design engineering 1); University of London (UCL), Faculty of Engineering Sciences (Engineering drawing and design); Politehnika University of Timisoara, Mechanical Engineering Faculty (Technical graphic and computer drawing); Budapest University of Technology and Economics, Faculty of Mechanical Engineering (Descriptive geometry, Fundamentals of CAD); Slovak University of Technology in Bratislava, Faculty of Mechanical engineering (Engineering graphics (CAD)).

Apparently, engineering graphic communications is a first-year basic course studied in all faculties of mechanical engineering in Serbia as well as in European countries under similar names. This shows how much this course is important in education of future technical engineers.

\section{Computer Usage in Technical Drawing}

Technical drawings demand a lot of efforts and time. People have always strived to simplify and shorten the procedure of making a drawing because it makes a significant item in overall expenses of production of an object or a machine. Computers and possibility of their mass exploita- 
tion have started a real revolution in technical drawing. Among other things, computers are machines for drawing and a place for storing drawings (Beazley \& Bond, 2003).

Development of information technologies, especially computers and corresponding software systems which made an important support to a designer during designing process, conditioned a new way of thinking in designing process. Today designers have a powerful tool which assures selection of the best solution in all steps of designing process at a particular time and in the particular conditions. In every moment a designer must have a clear vision of a series of actions which lead him in as quick and rational manner as possible to a desired model, i.e. standard technical documentation (Devedzic, 2004). Three-dimensional objects in engineering are often created by means of drawings. The process of modeling begins with a conception (idea) by describing an object by means of a 2D (two-dimensional) drawing and its specification

\section{Electronic Teaching Material}

In the past 30 years, developments in the ways of integrating communication technologies in education have caused the process and aims of the learning process to be questioned and redefined (Yazici \& Demirkaya, 2010). Educational materials are the most important element of distance learning. With traditional education they are only a support to teaching process where a teacher has the main role. However, in distance learning educational materials are the main source of new knowledge and skills. They are at the same time means of control of teaching process because they lead each student through the training process and towards desired goal. Their role is very complex and the effect they have on quality and result of distance learning is crucial.

\section{Efficiency of Electronic Learning in Engineering Graphics Teaching}

The research involved 127 students of technical programs of study $\left(1^{\text {st }}\right.$ year of study, Industrial Engineering, Engineering Management) at the Technical Faculty "Mihajlo Pupin" in Zrenjanin where the sample size was sufficient. The problem of research was efficiency of modern engineering graphics teaching, while the subject of the research was theoretical and empirical study of students' achievements obtained by application of innovative model of teaching engineering graphics. Innovative model is an electronic learning model in engineering graphics teaching.

The main purpose was to show the statistically significant possibility to raise the efficiency of engineering graphics teaching through theoretical research and by means of an electronic learning model application in higher technical education.

The sample includes two subsamples composed for the needs of pedagogical experiment with parallel groups: the first subsample embraced 62 students who made up the experimental group of respondents (E group). The E group took part in teaching according to a detailed experimental program of work. The other subsample comprised 65 students who made up a control group of respondents (K group) and who took part in usual teaching of engineering graphics with already used methods of work.

The idea was to use parallel, relatively balanced groups. This technique enabled us to compare results between two groups, one of them learning by traditional methods and the other learning by experimental methods (distance learning methods). The groups were balanced in number, gender, computer literacy. Computer literacy was established by means of a questionnaire on knowledge of information technology (Computer competency - subtest 1, Software competency- subtest 2 and Internet competency- subtest 3 ). After the tests had been done and the experiment implemented, efficiency of teaching and learning processes were checked. 
An experimental program was created for the needs of the research which comprised teaching contents of engineering graphics, teaching units Computer drawing and design (CAD) created according to the innovative teaching models. Within the research conducted, the teaching was weekly-based and lasted for seven days. The students' activities and tasks were defined in advance. Online activities comprised the following: the students had to review the teaching units planned for the current week; for each teaching unit the students had to solve a series of problems which allowed us to collect data about effectiveness of their learning; tutorials; after a teaching unit had been reviewed their work was based on self-testing.

For the successful work of projected learning system it is necessary to define scenario of its development and implementation (Table 1). In this case the scenario was projected in the following way (Letic, Davidovic, \& Desnica, 2007 ):

\begin{tabular}{|l|}
\hline \multicolumn{1}{|c|}{ Table 1. Scenario of development and implementation of the model } \\
\hline \multicolumn{1}{|c|}{ Calendar of activities } \\
(9 teaching topics - theory, practical exercises, test) \\
\hline Teaching topic I: Adjustment of basic CAD parameters (6 lessons) \\
\hline Teaching topic II: Basic and auxiliary drawing methods (4 lessons) \\
\hline Teaching topic III: Stylization and text editing on the drawings (4 lessons) \\
\hline Teaching topic IV: Methods of object modification on the drawing (3 lessons) \\
\hline Teaching topic V: Forming and editing of figured dimensions (3 lessons) \\
\hline Teaching topic VI: Graphic communication in engineering (4 lessons) \\
\hline Teaching topic VII: Preparation and printing of technical documentation (3 lessons) \\
\hline $\begin{array}{l}\text { Teaching topic VIII: Practical exercises (exercises: Start 2D, End 2D, Exercises for self- } \\
\text { control: Examples 2D; Drawing formats; Graphic communication; Records) }\end{array}$ \\
\hline Teaching topic IX: Exam questions \\
\hline Final meeting and evaluation \\
\hline
\end{tabular}

The students of all experimental groups could find the material on the website of the Faculty. Within experimental part of this research distance learning via the Internet was organized which involved testing and measuring parameters relevant for efficiency of this type of learning.

Research hypothesis - distance learning model in engineering graphics teaching has statistically significant influence on teaching process efficiency in higher technical education, i.e. learning model in engineering graphics teaching contributes to advancement of students' professional knowledge in finding solutions to real technical problems.

Research techniques and procedures:

- questioning - to establish the extent of knowledge and insight of teachers and students in possibilities of distance learning before and after the experiment, obtaining the students' opinion on advantages and disadvantages of this type of teaching organization;

- testing - to establish prior knowledge of students about engineering graphics teaching, i.e. initial knowledge test, as well as to establish the acquired knowledge after application of experimental program, i.e. final knowledge test. 
Research instruments: questionnaires and knowledge tests.

For the needs of this research the initial knowledge test was created in a form of a series of questions and the aim of this test was to establish initial state of experimental and control group (each question was worth a certain number of points used to from the final mark for each student, from 5 to 10). Initial test involved contents about descriptive geometry which the students acquired during their previous schooling. A good knowledge of this material was a prerequisite for understanding the contents which are a part of the experiment.

The final knowledge test was created for the needs of this research as a series of objective type questions and the aim of this test was to establish the final knowledge of experimental and control group (each question was worth a certain number of points used to from the final mark for each student, from 5 to 10$)$.

The results of the initial and final testing of student control and experimental group are shown in Table 2 and Figure 1.

Table 2. Students' performance on the initial and final test (number and \% grade on the test)

\begin{tabular}{|c|c|c|c|c|c|c|c|c|c|c|c|}
\hline \multicolumn{9}{|c|}{ K group } & \multicolumn{6}{c|}{ E group } \\
\hline \multicolumn{4}{|c|}{ Initial test } & \multicolumn{3}{|c|}{ Final test } & \multicolumn{3}{c|}{ Initial test } & \multicolumn{3}{c|}{ Final test } \\
\hline Grade & $\Sigma$ & $\%$ & Grade & $\Sigma$ & $\%$ & Grade & $\Sigma$ & $\%$ & Grade & $\Sigma$ & $\%$ \\
\hline 10 & 7 & 10.77 & 10 & 9 & 13.85 & 10 & 6 & 9.68 & 10 & 22 & 35.48 \\
\hline 9 & 9 & 13.85 & 9 & 10 & 15.38 & 9 & 7 & 11.29 & 9 & 16 & 25.81 \\
\hline 8 & 15 & 23.08 & 8 & 17 & 26.15 & 8 & 17 & 27.42 & 8 & 12 & 19.35 \\
\hline 7 & 18 & 27.69 & 7 & 16 & 24.62 & 7 & 15 & 24.19 & 7 & 5 & 8.06 \\
\hline 6 & 10 & 15.38 & 6 & 8 & 12.31 & 6 & 10 & 16.13 & 6 & 4 & 6.45 \\
\hline 5 & 6 & 9.23 & 5 & 5 & 7.69 & 5 & 7 & 11.29 & 5 & 3 & 4.84 \\
\hline & 65 & 100.00 & & 65 & 100.00 & & 62 & 100.00 & & 62 & 100.00 \\
\hline
\end{tabular}

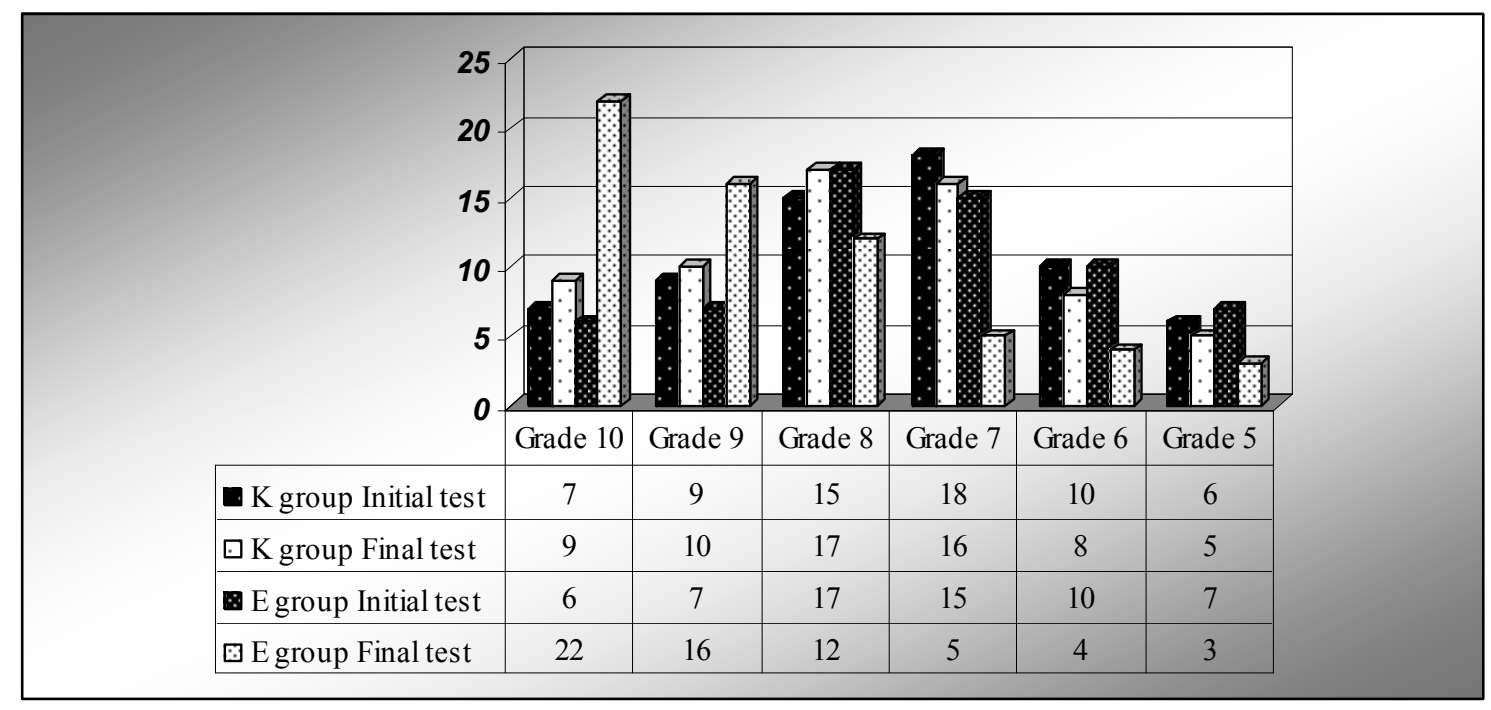

Figure 1. Comparative evaluation of initial and final knowledge test of experimental and control group 
Questionnaires for students and teachers - a questionnaire before research with the aim to show how much the students knew about distance learning, the questionnaire after research for experimental group students had the aim to offer an insight of students' impressions about performance of experimental program, i.e. innovative methods of work and learning. The questionnaire for teachers had the aim to establish the extent to which the teachers were ready to prepare and create educational material needed to implement a model of electronic learning (17 professors and teaching assistants participated in the questionnaire). The questionnaires were anonymous so that the students and teachers could express their opinion more freely.

Measuring of relevant parameters and analysis of the obtained results were performed by means of standard statistical methods. To test the hypothesis Mann Whitney U test and Wilcoxon's test were used to establish statistically significant difference between initial test results and final test results. The data were processed by means of SPSS 8.5 software.

\section{Discussion of the Research Results}

The p value (Asymp. Sig. (2-tailed) - table 3) must be less than 0.05 in order to have difference between control and experimental group. Since in this case $\mathrm{p}$ value $=0.768$, this indicator is not statistically significant, so it can be said that there is no difference between $\mathrm{K}$ and $\mathrm{E}$ group at the initial knowledge test.

\begin{tabular}{|c|c|c|c|c|}
\hline \multicolumn{5}{|c|}{ Table 3: Mann Whitney $U$ test results for initial tes } \\
\hline \multicolumn{5}{|c|}{ Ranks } \\
\hline \multirow{4}{*}{$\begin{array}{l}\text { inicijalni } \\
\text { test }\end{array}$} & $\mathrm{KE}$ & $\mathrm{N}$ & $\begin{array}{l}\text { Mean } \\
\text { Rank }\end{array}$ & $\begin{array}{l}\text { Sum of } \\
\text { Ranks }\end{array}$ \\
\hline & 0 & 65 & 64.92 & 4220.00 \\
\hline & 1 & 62 & 63.03 & 3908.00 \\
\hline & Total & 127 & & \\
\hline \multicolumn{5}{|c|}{ Test Statistics ${ }^{a}$} \\
\hline & \multirow{5}{*}{\multicolumn{2}{|c|}{$\begin{array}{l}\text { Mann-Whitney U } \\
\text { Wilcoxon W } \\
\text { Z } \\
\text { Asymp. Sig. (2-tailed) }\end{array}$}} & INICT & \\
\hline & & & 1955.000 & \\
\hline & & & 3908.000 & \\
\hline & & & -.296 & \\
\hline & & & .768 & \\
\hline \multicolumn{5}{|c|}{ a. Grouping Variable: KE } \\
\hline
\end{tabular}

Researching significance of differences in achievements between respondents of experimental and control groups at the initial and final tests, a significant progress of experimental group compared with control group was noticed ( $p$ value $=0.000$, Asymp. Sig. - table 4 ). A statistically significant increase of students' success resulted from the influence of experimental program which acted as an experimental factor with the corresponding manner of teaching. The difference between the control and experimental group is statistically significant with $95 \%$ certainty. Based on all previous results, null hypothesis is rejected which runs as follows: it is assumed that application of innovative models of engineering graphics teaching will have no effect on increase of students' achievement, quantity and quality of knowledge, while the hypothesis is accepted which runs as follows: a model of distance learning in engineering graphics teaching affects advancement of professional knowledge and increase of the level of students' knowledge. 


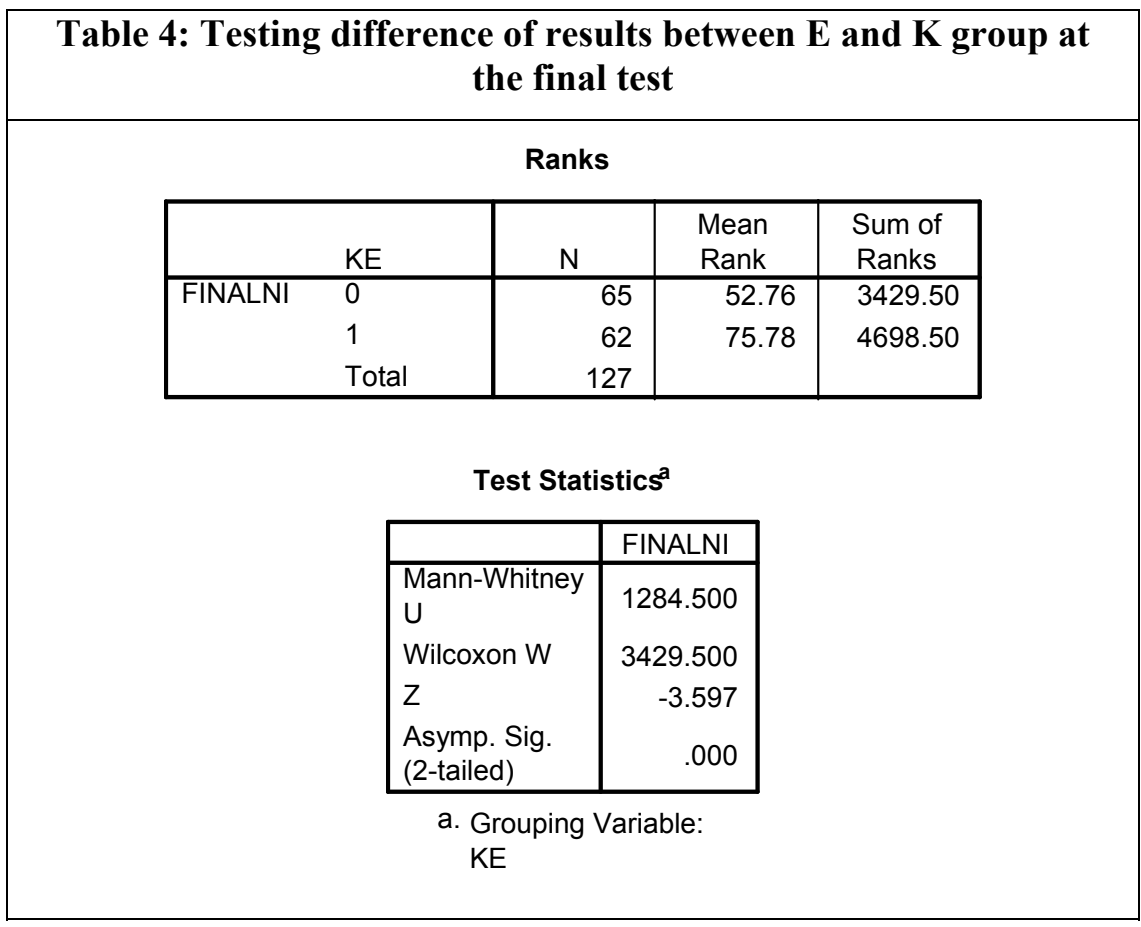

\section{Conclusion}

The general conclusion about the conducted research is as follows: the adequate application of innovative models of work in engineering graphics teaching based on a model of distance learning (learning by independent problem solving, learning by discovering, research-aimed learning,...) leads to a significant increase of students' success and accordingly contributes to greater efficiency of engineering graphics teaching. The quality of students' knowledge is improved because of insistence on professional knowledge advancement in solving real technical problems.

The presented results can serve as a base to direct more easily the course of some future researches. The research results indicate the need for wider and more frequent application of selected learning models, as well as the possible effects they would have in case of their longer and continuous application in engineering graphics teaching. The results of this research should complete professional knowledge of teachers in order to encourage them to apply more widely the given experimental program of work.

Information technologies in higher education may become very powerful teaching aids to support lectures and practicals because they encourage easier learning and understanding of presented teaching contents and contribute to high degree of motivation for work on formation of individual knowledge of students.

Further work in this area is possible, primarily in its improvement and in personalization of proposed teaching methods. Moreover, the future will see a possibility to further develop educational software and electronic textbooks and their application in all spheres of education, which will be assured by development of technological base, but also by development of awareness of our society that we live in the era of turbulent development of science and technology. 


\section{References}

Bates, T. (2001). National strategies for eLearning in post-secondary education and training. Fundamentals of educational planning, UNESCO.

Beazley, A., \& Bond, T. (2003). Computer-aided pattern design \& product development. Great Britain: Blackwell.

Bertoline, G., \& Wiebe, E. (2002). Fundamentals of graphics communication (3rd ed.). McGraw-Hill.

Desnica, E., Letic, D. \& Navalusic, S. (2010). Concept of distance learning model in graphic communication teaching at university level education. Journal TTEM - technics, technologies, education, management, 5(2), 378-388.

Devedzic, G. (2004). Software solution of CAD/CAM systems. Mechanical faculty in Kragujevac, Kragujevac.

Gligoric, R., \& Milojevic, Z. (2004). Technical drawing - Engineering communication. University of Novi Sad, Faculty of Agriculture, Novi Sad.

Herrero-Martin, R., Solano-Fernandez, I. M. \& Solano-Fernandez, J. P. (2008). New teaching methodologies in engineering within European space for higher education. International Association for Technology, Education and Development (IATED)" Valencia, Spain.

Lee, K. (1999). Principles of CAD/CAM/CAE systems. Addison-Wesley.

Letic, D., Davidovic, B., \& Desnica, E. (2007). ECDL (Europian Computer Driving Licence) CAD V. 1.5 computer drawing and design. Cacak: Computer Bibliothec.

Letic, D., \& Desnica, E. (2007). 3D modeling and visualization - application in AutoCAD. Technical faculty "Mihajlo Pupin", Zrenjanin.

Miltenoff, P., Hoover, J., \& Tzokov, G. (2008). Online interaction among students and faculty: A comparative study. Proceedings of the Informing Science \& IT Education Conference (InSITE) 2008, 77-90. Retrieved April, 2009, from http://proceedings.informingscience.org/InSITE2008/InSITE08p077090Mlten428.pdf

Rogers, P. (2009). Encyclopedia of distance learning. Information Science Reference, Western Cooperative for Educational Telecommunications.

Rosenberg, M. (2006). Beyond e-learning: Approaches and technologies to enhance organizational knowledge, learning, and performance. John Wiley \& Sons.

Saade, G., Raafat, P. \& Huang, Q. (2008). Prototyping a learning management system for higher education. Proceedings of the Informing Science \& IT Education Conference (InSITE) 2008, 155-165. Retrieved April, 2009, from http://proceedings.informingscience.org/InSITE2008/InSITE08p155165Saade461.pdf

Yazici, H., \& Demirkaya, H. (2010). Views of student teachers on information technology integration in geography teaching. Scientific Research and Essays, 5(13), 1746-1753. 

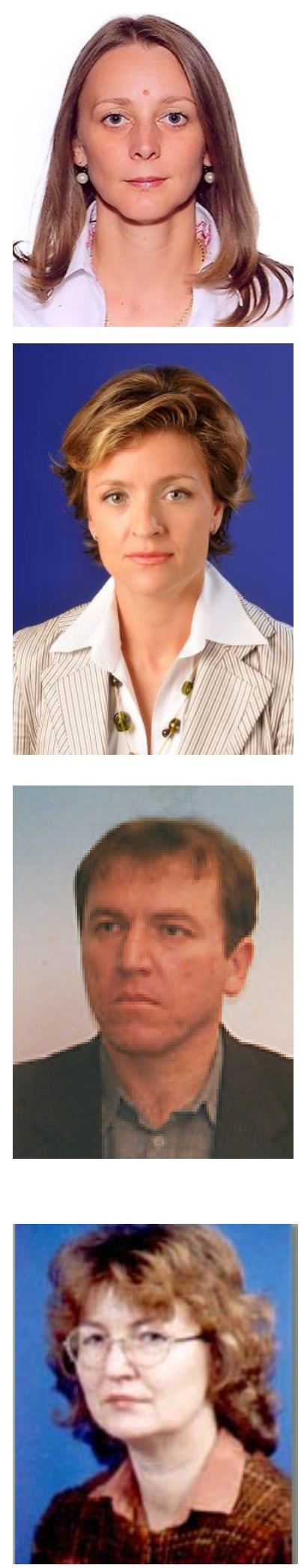

\section{Biographies}

Eleonora Desnica is a teaching assistant at the Technical Faculty "Mihajlo Pupin", Zrenjanin, Serbia. She got her PhD degree in technical sciences at the University of Novi Sad in 2010. She teaches courses in Technical drawing with computer graphics, Mechanics, Computer Aided Design, Principles of machine design. Her area of interest are computer supported technologies in mechanical engineering and their application in education.

Biljana Gemović is lecturer at the vocational program of mechanical and engineering graphics and in teaching vocational subjects in the field of Technical Engineering (Computer graphics, CAD) at the Higher Education Technical School of Professional Studies, Novi Sad, Serbia. Her field of interest is improving the quality of management and computer engineering, as well as innovation program for engineering education in the field of computer graphics and CAD. She has extensive experience in the application of CAD technology, implementation of quality system ISO 9001, ISO 18001 and HACCP.

Duško Letić is an associate professor at the Technical Faculty "Mihajlo Pupin", Zrenjanin, University of Novi Sad, Serbia. He is a member of the Informatics Technology Chair. He has become engaged in these subjects: Operating Researches, Computer - Aided Design, Computer Graphic Modelling and Computer Applications. His field of interest during last years are special functions and optimisation methods in mathematics and engineering.

Radojka Gligorić is a professor at the Faculty of Agriculture, University of Novi Sad, Serbia, for the following subjects: Engineering communication and Elements and mechanisms of agricultural machinery. Her field of interest during last years are Biotechnology. She published about 350 scientific papers in journals and at scientific meetings. She is the author of three university books and many scientific monographs. 